\title{
Adaptation of the forecasting system to control Black Leaf Streak Disease of banana in the specific conditions of Dominican Republic
}

Claire Guillermet ${ }^{1}$, Roxane Le Guen ${ }^{2}$, Eric FourE ${ }^{3}$, Carlos CeSPEDes ${ }^{4}$, Luc DE LAPEYRE De BeLlaIRE ${ }^{3 *}$

${ }^{1}$ CIRAD, UPR Syst. Bananes Ananas, Quartier Petit Morne, BP 214, 97285 Le Lamentin Cedex 2, Martinique ${ }^{2}$ CIRAD, UPR Syst. Bananes Ananas, Ofic. Adobanano, Indenor 3er piso,

Av. Miguel Crespo,

Mao Valverde,

Repub. Dominicana

${ }^{3}$ CIRAD, UPR Syst. Bananes Ananas, TA B-26/PS4,

Blvd. la Lironde, 34398

Montpellier Cedex 5, France, luc.de_lapeyre@cirad.fr

${ }^{4}$ Inst. Domin. Investig. Agropecu. For., Centro Norte, Avenida Imbert No. 5, La Vega Repub. Dominicana

* Correspondence and reprints

Received 11 December 2013 Accepted 17 January 2014

Fruits, 2014, vol. 69, p. 261-278 (C) 2014 Cirad/EDP Sciences All rights reserved

DOI: 10.1051/fruits/2014016 www.fruits-journal.org

RESUMEN ESPAÑOL, p. 278

\section{Adaptation of the forecasting system to control Black Leaf Streak Disease of banana in the specific conditions of Dominican Republic.}

\begin{abstract}
Introduction. Black Leaf Streak Disease (BLSD) is the most important foliar disease affecting banana production worldwide. A forecasting system has been developed and implemented in various countries aiming at optimal control of BLSD through minimum applications of fungicide. In Dominican Republic, favorable dry climatic conditions contrast with serious organizational issues for BLSD control. Our objective was to evaluate the adaptation of this forecasting strategy in these specific conditions. Materials and methods. Fungicide resistance analyses were carried out in the northwestern region of Dominican Republic, in order to determine the appropriate spectrum of systemic fungicides for the forecasting strategy. Three field experiments were set up on commercial farms where disease evolution was monitored every week, on reference plots, in order to decide the pertinence of fungicide applications. Results. Fungicide resistance to QoI fungicides and strong sensitivity reduction to DMI (Demethylation Inhibitor) fungicides were detected in all farms. In spite of these limitations in the use of some fungicide groups, disease control was achieved with a limited number of fungicide applications (6-9), as compared with 13-26 applications in most commercial farms of Dominican Republic over the same period. Discussion. The calculation of an indicator of the efficiency of the chemical control confirmed the potential of the forecasting strategy, underlining the influence of crop management as well as the neighboring environment of the farms on its efficiency. The requirements for further generalization of this system to commercial farms of this country are discussed.
\end{abstract}

Dominican Republic / Musa / plant disease control / Mycosphaerella fijiensis / forecasting

Adaptation du système d'avertissement biologique de la maladie des raies noires dans les conditions spécifiques de la République dominicaine.

Résumé-Introduction. La Maladie des Raies Noires (MRN) est la maladie foliaire la plus importante affectant la production bananière à travers le monde. Un système d'avertissement biologique a été développé et mis en place dans plusieurs pays visant à un contrôle optimal de la MRN avec un nombre minimal d'applications de fongicides. En République dominicaine, les conditions climatiques sèches sont favorables au contrôle de la maladie, mais contrastent avec des lacunes organisationnelles importantes. Notre objectif a été d'évaluer l'adaptation de la stratégie d'avertissement dans ces conditions spécifiques. Matériel et méthodes. Des analyses de résistance aux fongicides ont été menées dans la région Nord Ouest du pays afin de déterminer la gamme de fongicides appropriée pour l'avertissement. Trois expérimentations ont été menées sur des plantations commerciales avec un suivi hebdomadaire de l'évolution de la maladie, sur des postes de référence, afin de décider de la pertinence de la réalisation d'un traitement. Résultats. Une résistance aux fongicides de type QoI et une forte réduction de la sensibilité aux DMI (Demethylation Inhibitors) ont été détectées dans toutes les plantations. Malgré ces limitations dans l'usage de certains groupes de fongicides, la maladie a pu être contrôlée avec un nombre limité de traitements (6 à 9), contre 13 à 26 traitements effectués dans la plupart des plantations commerciales du pays sur la même période. Discussion. Le calcul d'un indicateur d'efficacité du contrôle chimique a confirmé l'intérêt de la stratégie d'avertissement, soulignant l'influence des pratiques culturales ainsi que celle de l'environnement voisin de la plantation sur son efficacité. Les dispositions nécessaires à la généralisation de ce système aux plantations commerciales du pays sont discutées.

République dominicaine / Musa / lutte antimaladie des plantes / Mycosphaerella fijiensis / technique de prévision 


\section{Introduction}

Bananas are one of the main agricultural products in the world, and the main fruit crop, with an annual production of about $110 \mathrm{Mt}$ [1]. Production for international trade is limited to a small number of countries, but for which banana production is economically and socially important [2]. Black Leaf Streak Disease (BLSD) is the most costly and damaging disease affecting the banana industry worldwide [3], since the unique banana group of cultivars grown for exportation (Musa acuminata, AAA, Cavendish subgroup) is highly susceptible. This foliar disease is caused by the fungal pathogen Mycosphaerella fijiensis. The first symptoms are identified as reddish-brown streaks, becoming larger streaks eventually leading to leaf necrosis. In the absence of suitable control, the photosynthetic capacity of leaves is significantly reduced [4], which often results in a yield loss of $20 \%$ to $80 \%$ $[5,6]$. However, the most important effect of BLSD is the reduction of fruit greenlife [ 4 , 7]. Effectively, as a climacteric fruit, bananas are harvested still green, at the pre-climacteric stage. Fruit ripening is then artificially induced by ethylene treatment in commercial ripening rooms. In order to withstand maritime shipping, greenlife must be superior to the time between harvest and artificial ripening [8]. A direct relationship between disease severity and greenlife reduction has recently been shown [9-11].

With 18,300 ha, and more than 2,000 producers, banana production has major economic and social importance in Dominican Republic [12]. From the 600,000 t produced in $2010,328,000 \mathrm{t}(52 \%)$ were exported, generating a major source of foreign exchange (FOB value of USD\$ $180 \mathrm{M}$ ). The rest of the production supplies local markets and domestic consumption as a food security crop [13]. Banana is also a source of permanent work for the rural population [13], generating more than 50,000 direct and indirect jobs [12]. From its origin in Southeast Asia, Musa. fijiensis was first detected in the Americas in the early 70s, in Honduras [3]. In Dominican Republic, BLSD was first reported in 1996, in the Montecristi province [14, 15]. It quickly spread to all the country, and now represents a major constraint to fruit exportation [16]. At the beginning, the BLSD impact on the banana industry was not severe, but it has increased over the years. Indeed, until 2008, six to ten chemical applications per year were necessary [16], compared with 16 to 20 cycles today, with some situations up to 36 cycles [12]. Furthermore, hundreds of farmers stopped exportation in 2011, due to severe BLSD, accounting for the loss of about $96000 \mathrm{t}$ of bananas, valued at more than USD $\$ 76 \mathrm{M}$. The cost of control also increased, up to an average of USD $\$ 1,135 \cdot \mathrm{ha}^{-1}$, and presently the control of BLSD has become a serious challenge for the banana industry in this country [12].

A warning system developed for the control of Sigatoka disease (SD, due to M. musicola) has been adapted for BLSD [17-20]. This strategy aims to optimize control of the disease, with minimum fungicide applications, which would result in a lower cost of control, lower risk of fungicide resistance and lower environmental negative impact. The forecasting system relies on several key factors such as (i) early disease detection, (ii) fast aerial spraying, (iii) a strong curative effect through the use of systemic fungicides in $15 \mathrm{~L} \cdot \mathrm{ha}^{-1}$ of mineral oil, (iv) fungicide resistance management, and (v) centralization and generalization of control over the whole banana-producing area [3, 20].

Since the 70 s this forecasting system has allowed good control of both diseases through 5-8 (Sigatoka disease, in the French West indies) to 10-15 annual applications (Black Leaf Streak Disease, in Ecuador, Cameroon and Ivory Coast), when 30 to 60 systematic sprays are carried out in most Latin American countries [20]. However, the regular and intensive use of systemic fungicides has, in some situations, led to the emergence of resistant strains in $M$. fijiensis populations [20, 21]. Consequently, as in Cameroon, the control has progressively shifted to a systematic fungicide application of contact fungicides (more than 40 applications per year), showing that this strategy must be adapted to local conditions in order to ensure its sustainability [21].

The objective of our work was to adapt this warning system method to the Dominican Republic, taking into account the specific conditions in this country: (i) favorable 
Table I.

Fungicides used in the different culture media for the germination tests of Mycosphaerella fijiensis conidia.

\begin{tabular}{|c|c|c|c|}
\hline Mode of action & Active ingredient & $\begin{array}{c}\text { Concentration used } \\
\left(\mu \mathrm{g} \cdot \mathrm{mL}^{-1}\right)\end{array}$ & Observations \\
\hline \multirow[t]{2}{*}{ DMI } & Propiconazole & 0.1 & Length of germ tube \\
\hline & Difenoconazole & 0.1 & Length of germ tube \\
\hline Antimitotic & Methyl thiophanate & 5 & Morphology of the germ tube \\
\hline Qoi & Azoxystrobin & 10 & Length of the germ tube \\
\hline Control & None & 0 & Length of the germ tube \\
\hline
\end{tabular}

climatic conditions for a forecasting system, because of annual precipitation lower than that in most of the banana production areas of the world (average $700 \mathrm{~mm} \cdot \mathrm{year}^{-1}$ ), but (ii) a difficult organizational context for BLSD control, since each banana grower (among more than 2000) implements his own strategy on his farm without any coordination [22]. This work was conducted in two steps. Firstly, fungicide resistance monitoring was embarked upon to identify the different systemic fungicides that could be used, ensuring a strong curative effect. Indeed, very few consistent data were available in this country. Secondly, three field trials were successively set up on three commercial farms with different agronomic and climatic conditions, in order to adapt the forecasting strategy, and to evaluate its performance under these specific conditions.

\section{Materials and methods}

\subsection{Fungicide resistance analysis}

\subsubsection{Leaf sampling}

Leaf samples were collected from two commercial farms, of (14 and 17) ha, located in Esperanza and Guayacanes, Valverde province, in the northwestern region of Dominican Republic. A limb fragment $[(15 \times$ 20) $\mathrm{cm}$ ] bearing stage 2-3 lesions [23] was collected on each of 25 banana plants selected randomly on the same banana plot. Leaf samples were shipped to Montpellier, France, for further analysis. Leaf samples were collected in two periods: (i) before the experiment of the forecasting strategy (Esperanza and Guayacanes) and (ii) one year after the beginning of the experiment (Esperanza).

\subsubsection{Fungal isolation and production of conidia}

Conidia produced on the young stage 23 lesions were transferred to agar plates $\left(30 \mathrm{~g} \cdot \mathrm{L}^{-1}\right)$ and 50 single conidia were isolated (two isolates per leaf). Each isolate was further grown on V8 300sp medium ( $100 \mathrm{~mL}$ of $\mathrm{V} 8$ vegetable juice, $0.2 \mathrm{~g}$ of $\mathrm{CaCO}_{3}, 20 \mathrm{~g}$ of agar, $900 \mathrm{~mL}$ of water, and $\mathrm{pH}$ adjusted to 6) at $20{ }^{\circ} \mathrm{C}$ under continuous light to produce conidia that were used for germination tests.

\subsubsection{Germination tests of conidia}

After 10 days a fragment of each fungal colony grown on the V8 300sp medium was transferred into a microtube with $200 \mu \mathrm{L}$ of sterile distilled water. After vortex agitation, a micro-drop of the conidial solution was transferred onto the various agar $\left(20 \mathrm{~g} \cdot \mathrm{L}^{-1}\right)$ media amended or not with different fungicide concentrations (table I).

Forty-eight hours after cultivation on the different agar + fungicide media, conidial germination was observed under a microscope [24]:

- For each isolate from cultivation with demethylation inhibitor (DMI) fungicides (propiconazole, difenoconazole) and QoI fungicides (azoxystrobin), the germ tube length of conidia was measured with a micrometer on the control (Lc) and on the fungicide-amended medium (Lf).

- For each isolate from cultivation with antimitotics (methyl thiophanate), the morphology of the germ tube was observed and 


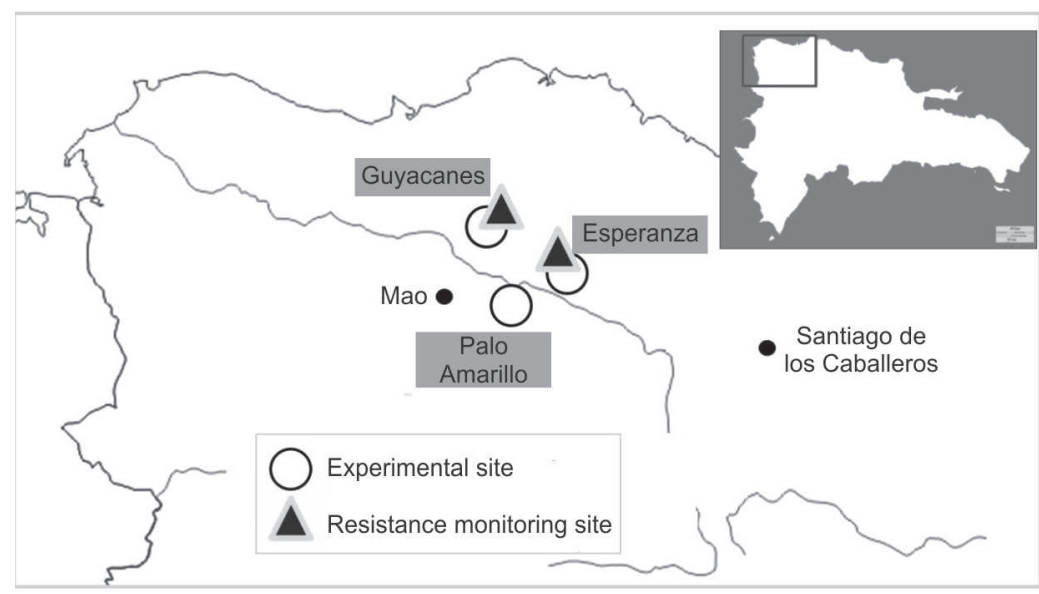

Figure 1.

Dominican Republic map with situation of sampling sites for the analysis of fungicide resistance and commercial farms where a forecasting strategy was tested.

classified as (i) normal (germination similar to the control); (ii) twisted (distortion of the germ tube); (iii) shorter (germ tubes not distorted, but length substantially shorter than the control), or (iv) not germinated.

The results were compared with those obtained from a non-treated banana farm in Cameroon (Cameroon baseline).

\subsubsection{Data analysis}

For each strain from cultivation with DMI fungicides (propiconazole, difenoconazole), the growth inhibition (GI) was calculated as $\{\mathrm{GI}=[1-(\mathrm{Lf} / \mathrm{LC})] \times 100\}$. The average value of each population sampled was calculated and compared with the value of the baseline sample. The distribution of sensitivity of each strain using the following growth inhibition classes: [0-10[, [10-20[, [20-30[, [30-40[, [40-50[, [50-60[, [60-70[, [70-80[, [80-90[ and [90-100] was represented, and the percentage of strains with less than 50\% GI was also calculated in order to characterize the deviation of sensitivity of the fungal population analyzed (in baseline samples no strains have less than 50\% GI).

For each strain from cultivation with Qol fungicides (azoxystrobin), the growth inhibition (GI) was calculated as $\{\mathrm{GI}=[1-$ (Lf / Lc) $\times 100\}$. The average value of each population sampled was calculated and compared with the value of the baseline sample. The distribution of sensitivity of each strain using the following growth inhibition classes: [0-10[, [10-20[, [20-30[, [30-40[, [4050[, [50-60[, [60-70[, [70-80[, [80-90[ and [90-100] was represented. The percentage of strains with less than $40 \%$ GI was also calculated in order to estimate the percentage of resistance in each population (all strains with GI $<40 \%$ are resistant, but the proportion of resistant strains might be underestimated with this cut-off limit).

Resistant strains from cultivation with antimitotics (methyl thiophanate) are those with a normal or short germ tube. Therefore, for each population sampled, the percentage of resistant strains was calculated and compared with the baseline sample ( $0 \%$ of resistant strains).

\subsection{Field experiments of the warning method on commercial farms}

The experiments were set up (i) from April 2011 to March 2012 in Esperanza (14 ha), (ii) from April 2012 to April 2013 in Palo Amarillo (20 ha), and from April 2012 to April 2013 in Guayacanes (17 ha), all these farms being located in the Mao, Valverde province (figure 1).

\subsubsection{Data collection}

The development of Black Leaf Streak Disease was assessed every week through various parameters, following Fouré's method $[3,17]$.

The "Stage of Evolution of Disease" (SED) represents the rate of disease development, which reflects the climatic conditions, and the intensity of the infection [20]. It relies on the early detection of the first disease symptoms on the youngest banana leaves (ranks 1 to 4). This detection will allow blocking their evolution towards necrotic spots, and sexual sporulation, thanks to the early application of a curative fungicide. Decrease in the SED after an application therefore reflects its efficiency.

The "Youngest Leaf bearing Streaks" (YLSt) is the rank of the youngest leaf bearing symptoms of the disease. It reflects the effect of the climatic conditions and fungicide spraying program on the incubation period of the disease. This parameter is complementary to the SED, as it enables one to understand the evolution of epidemiological conditions, especially when no symptom is observed on the first four leaves. 
The "Youngest Leaf Spotted" (YLS) is the youngest leaf bearing necrotic lesions. Evolution of the YLS being a balance between the rate of necrotic formation and the foliar emission rate, its evolution allows understanding the efficiency of the fungicide control to reduce necrotic formation: (i) if the value of the YLS decreases, the chemical control is failing because necrotic formation is faster than leaf emission; (ii) if the YLS is increasing, the chemical strategy is efficient in slowing down the necrotic formation.

The "Number of Functional Leaves at Harvest" (NLH) is calculated as the sum of green portions of remaining leaves. It was evaluated every week on different banana trees at the harvest stage. It reflects the efficiency of the chemical strategy, and is used as a potential indicator for fruit exportability. Banana companies generally use an empirical threshold of the NLH (3-5 according to the company ) in order to decide which bunches are exportable or not.

Daily rainfall was recorded during all the experiments in order to appreciate the potential influence of rainfall on ascospore release.

\subsubsection{Timing of fungicide applications}

A graphic representation of the SED, YLSt, YLS, NLH and precipitation was carried out weekly after field observations. The decision for a new application was a synthesis of all these parameters.

\subsubsection{Fungicide applications}

Once the decision was taken, the application was to be executed within 2 days. The type of fungicide used was a balance between a general principle of rotation of fungicides with different modes of action, and the need for a strong curative effect at the time of the decision. To ensure a strong curative effect of the applications [25], only systemic fungicides mixed in pure mineral oil were used. They were selected according to the results of the resistance monitoring carried out before the experiment. Only fungicides with an acceptable level of sensibility were to be used. Availability of the different products in Dominican Republic was then checked, as was their formulation, which had to be compatible for mixtures in pure mineral oil at a $15 \mathrm{~L} \cdot \mathrm{ha}^{-1}$ rate. Use of mineral oils strengthens the curative effect of the application because of their fungistatic effect [25]. The good quality of the oil is essential and must fit with the norms defined by Cuillé and Blanchet [26]. Viscosity $4^{\circ}$ to $7^{\circ}$ Engler at $20^{\circ} \mathrm{C}$ and a sulfonation index lower than $85-90 \%$ are required.

During and after each application, the quality of the spraying was evaluated: (i) through the observation of droplet movement during the flight, and (ii) observation of oil deposits on the leaves, to evaluate product coverage in different plots of the farm.

\section{Results}

\subsection{Fungicide resistance analysis before the field experiment}

\subsubsection{Demethylation inhibitor (DMI) fungicides}

A strong loss of sensitivity to propiconazole was observed (table II). The mean percentage of growth inhibition was very low on both farms, 0\% and 29\% in Guayacanes and Esperanza, respectively, as compared with $74 \%$ in the untreated farm. A high proportion of the population in Guayacanes (100\%) and Esperanza (74\%) had a growth inhibition lower than 50\% (no strains were inhibited less than $50 \%$ in the non-treated farm).

For difenoconazole, a strong shift in sensitivity was also observed. The mean percentage of growth inhibition was very low on both farms, Guayacanes (21\%) and Esperanza (51\%), as compared with $77 \%$ in the untreated farm. In addition, $40 \%$ of the strains showed low growth inhibition $(<50 \%)$ in Esperanza, and up to $95 \%$ in Guayacanes, whereas none of the Cameroon baseline strains were in this class.

\subsubsection{Qol fungicides}

For azoxystrobine, at least $18 \%$ of the strains from Esperanza and 30\% from Guayacanes were resistant (growth inhibition < 40\%) (table III), showing a strong QoI resistance in fungal populations of these two farms. 





Table IV.

Percentage of resistant strains of Mycosphaerella fijiensis to methyl thiophanate $\left(5 \mu \mathrm{g} \cdot \mathrm{mL}^{-1}\right)$ in various Dominican banana farms.

$\begin{array}{lrcrr}\text { Methyl thiophanate } & \text { \% Resistant } & \text { \% Susceptible } & \text { Number of strains } \\ \text { Results } 2011 & \text { Esperanza } & 2 & 98 & 50 \\ & \text { Guayacanes } & 0 & 100 & 15 \\ \text { Results } 2012 & \text { Esperanza } & 0 & 100 & 100\end{array}$

\begin{tabular}{|c|c|c|c|c|c|}
\hline Mode of action & Potential products & $\begin{array}{c}\text { Curative } \\
\text { effect }\end{array}$ & $\begin{array}{l}\text { Resistance } \\
\text { risk }\end{array}$ & $\begin{array}{c}\text { Resistance } \\
\text { in Dominican Republic }\end{array}$ & $\begin{array}{l}\text { Potential use in the forecasting } \\
\text { experiment }\end{array}$ \\
\hline DMI & $\begin{array}{c}\text { Tilt } 25 \mathrm{EC} \\
\text { Sico } 25 \mathrm{EC} \\
\text { Opal } 7,5 \mathrm{EC} \\
\text { Silvacur } 30 \mathrm{EC} \\
\text { Folicur } 25 \mathrm{EW}\end{array}$ & ++++ & +++ & Yes & Limited \\
\hline Qol & Tega 25 SC & ++++ & +++++ & Yes & No \\
\hline Antimitotic & $\begin{array}{l}\text { Topsin M70 OD } \\
\text { Callis }\end{array}$ & +++ & ++++ & No & $\begin{array}{l}\text { Yes (no oil formulation available } \\
\text { in Dominican Republic) }\end{array}$ \\
\hline SBI class II & $\begin{array}{c}\text { Volley } 88 \mathrm{OL} \\
\text { Impulse } 80 \mathrm{EC}\end{array}$ & ++ & $+/-$ & nd & Yes \\
\hline Pyrimidin & Siganex $60 \mathrm{SC}$ & ++ & + & nd & Yes \\
\hline SDH inhibitors & $\begin{array}{c}\text { Cumora } \\
\text { Reflect } 125 \mathrm{EC}\end{array}$ & +++ & nd & nd & $\begin{array}{l}\text { Yes (not available until } \\
\text { November 2012) }\end{array}$ \\
\hline
\end{tabular}

\subsubsection{Antimitotic fungicides}

For methyl thiophanate (table IV), almost all strains had twisted morphology, characteristic of susceptible populations as encountered on non-treated farms. None of the strains from Guayacanes and only $2 \%$ of the strains in Esperanza were resistant.

These results led us to draft a list of the potential fungicides to be used for the experiment, limited to the few families and few products available in Dominican Republic (table V). Since QoI resistance was demonstrated, these products could not be used in the forecasting strategy. The significant shift in sensitivity to DMI fungicides led us to limit the use of these fungicides drastically, ordinary important components of the strategy. If used, these fungicides would be mixed with another fungicide (SBI class II) in order to reinforce their curative effect. Antimitotics could be used, but unfortunately no for- 


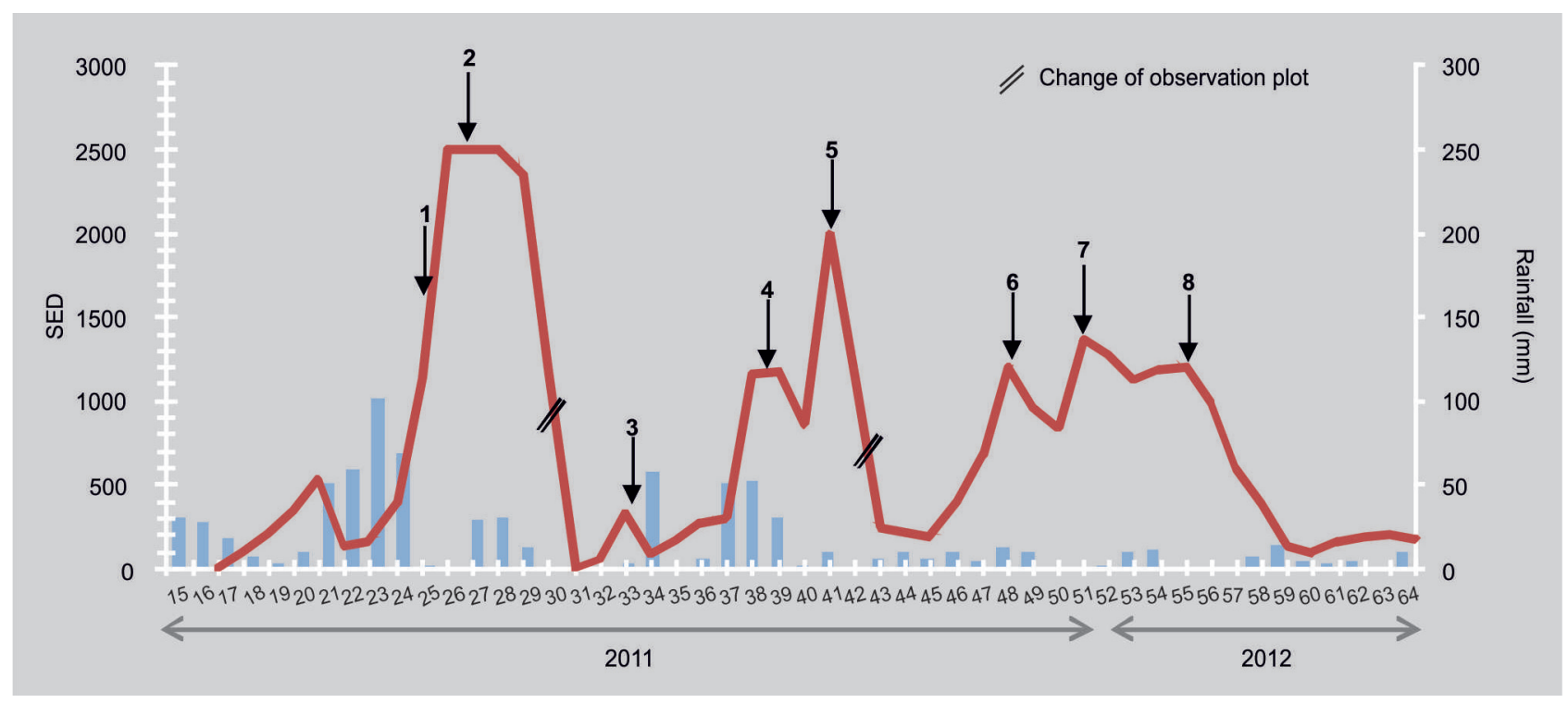

Figure 2.

Weekly variations of the Stage of Evolution of the Disease (SED) in Esperanza (Dominican Republic). mulation compatible with oil was available in Dominican Republic. The SBI class II and pyrimidins could be used without restriction because these fungicides are generally not affected by fungicide resistance. However, they have a limited curative effect and cannot be used efficiently in some situations. The new family of the SDH inhibitors could be used, but were not available at the beginning of the experiment.

\subsection{Disease control over a one-year period}

Generally, a new fungicide application was decided when a significant increase in the Stage of Evolution of Disease (SED) occurred. However, this decision was adapted to the specific climatic conditions of this country (shown by rainfall data) and the evolution of the Youngest Leaf bearing Streaks (YLSt) and also to the efficiency of the applications in the context of fungicide resistance [shown by SED evolution after the fungicide application and by the evolution of the Youngest Leaf Spotted (YLS)]. For instance, during dry periods, slight increases in the SED did not lead to a new fungicide application when the YLS and YLSt remained at high values. On the other hand, the fungicide application was not considered to be efficient when the SED did not decrease rapidly and the YLS started to decrease significantly. In this case a new fungicide application was decided.

\subsubsection{In Esperanza}

Over a one-year period, eight fungicide applications were carried out according to the variations of disease evolution (figures 2, 3, table VI). During this experiment, the delay between the decision and application varied from (2 to 10) days (table VI), depending on several factors such as (i) grower reactivity, (ii) some delays in product purchase, (iii) product availability and (iv) delays of the spraying company. These delays are far from the requirements of the forecasting strategy, and the efficiency of some applications (very low control duration for treatments 1 and 6 , table $V I$ ) was altered by being carried out too late. Out of eight applications, seven were undertaken in optimal climatic conditions. One application (treatment 6) was carried out later in the morning, when the temperature was higher than $28{ }^{\circ} \mathrm{C}$, and poor coverage of the product was observed. For other applications, the quality of the coverage proved to be acceptable.

More specifically, the first fungicide application decided on at week 23 was carried out 10 days later, and did not allow good disease control. A second application (mixture of a DMI with a SBI class II) was necessary to achieve further SED decrease. 


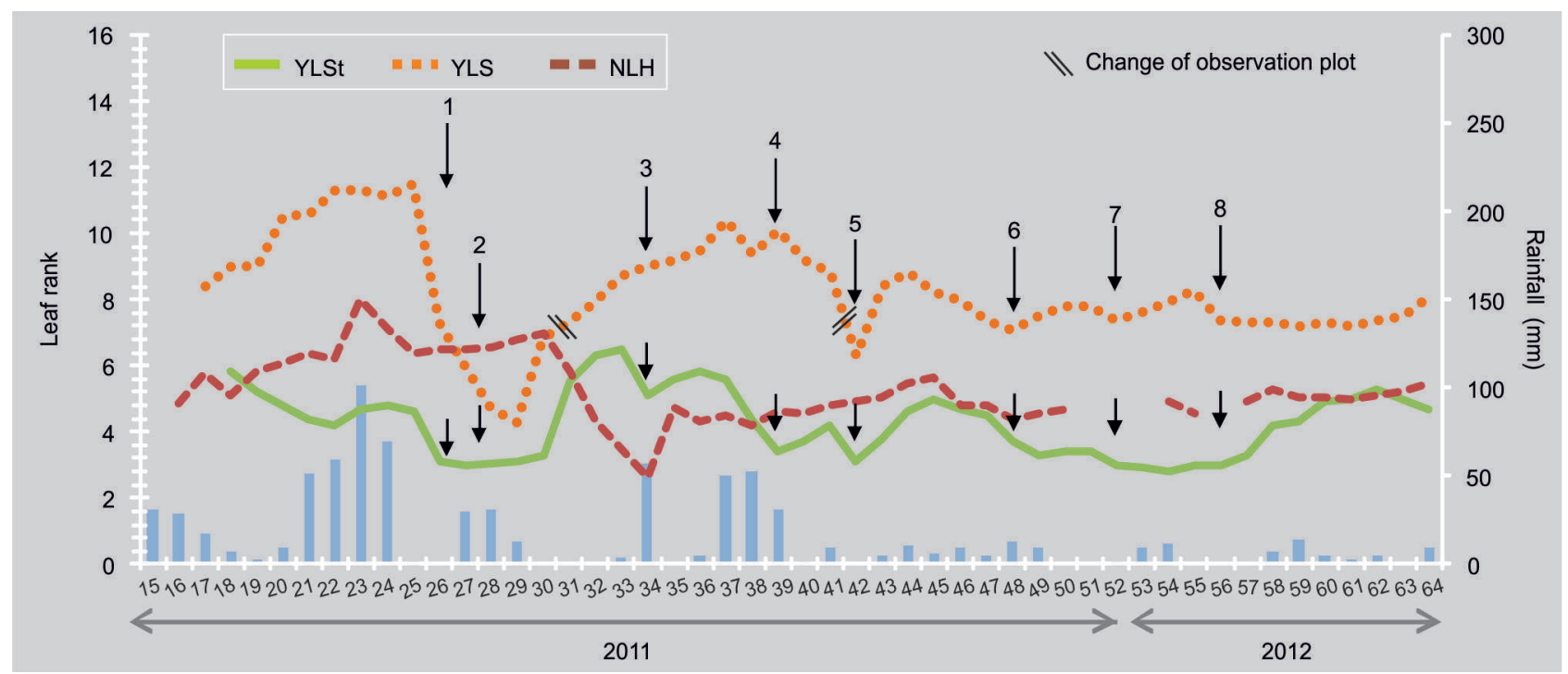

\section{Figure 3.}

Weekly variations of the Youngest Leaf Bearing Streaks (YLSt), Youngest Leaf Spotted (YLS) and Number of Leaves at Harvest (NLH) in Esperanza (Dominican Republic).

\section{Table VI.}

Description of the applications carried out for control of Black Leaf Streak Disease (BLSD) in a banana farm in Esperanza (Dominican Republic).

\begin{tabular}{|c|c|c|c|c|c|}
\hline $\begin{array}{l}\text { Number of the } \\
\text { application }\end{array}$ & $\begin{array}{l}\text { Days between decision } \\
\text { and application }\end{array}$ & $\begin{array}{l}\text { Efficiency of the application } \\
\text { (weeks) }\end{array}$ & Product & Active ingredient & $\begin{array}{l}\text { Mineral oil } \\
\left(15 \mathrm{~L} \cdot \mathrm{ha}^{-1}\right)\end{array}$ \\
\hline 1 & 9 & 2 & Volley $0.5 \mathrm{~L} \cdot \mathrm{ha}^{-1}$ & Fenpropimorph & Orange Oil \\
\hline 2 & 5 & 7 & $\begin{array}{l}\text { Volley } 0.5 \mathrm{~L} \cdot \mathrm{ha}^{-1}+ \\
\text { Opal } 1 \mathrm{~L} \cdot \mathrm{ha}^{-1}\end{array}$ & $\begin{array}{l}\text { Fenpropimorph }+ \\
\text { epoxiconazole }\end{array}$ & Spraytex \\
\hline 3 & 2 & 5 & Siganex $0.5 \mathrm{~L} \cdot \mathrm{ha}^{-1}$ & Pyrimethanil & Orange Oil \\
\hline 4 & 2 & 3 & Topsin $300 \mathrm{~g} \cdot \mathrm{ha}^{-1}$ & Methyl thiophanate & Spraytex \\
\hline 5 & 3 & 7 & $\begin{array}{l}\text { Sico } 0.4 \mathrm{~L} \cdot \mathrm{ha}^{-1}+ \\
\text { Volley } 0.5 \mathrm{~L} \cdot \mathrm{ha}^{-1}\end{array}$ & $\begin{array}{l}\text { Difenoconazol + } \\
\text { fenpropimorph }\end{array}$ & Spraytex \\
\hline 6 & 10 & 3 & Siganex $0.4 \mathrm{~L} \cdot \mathrm{ha}^{-1}$ & Pyrimethanil & Banole \\
\hline 7 & 6 & 4 & Topsin $300 \mathrm{~g} \cdot \mathrm{ha}^{-1}$ & Methyl thiophanate & Banole \\
\hline 8 & 5 & $>9$ & $\begin{array}{l}\text { Volley } 0.5 \mathrm{~L} \cdot \mathrm{ha}^{-1}+ \\
\text { Opal } 1 \mathrm{~L} \cdot \mathrm{ha}^{-1}\end{array}$ & $\begin{array}{l}\text { Fenpropimorph + } \\
\text { epoxiconazole }\end{array}$ & Banole \\
\hline
\end{tabular}

As a consequence of bad disease control, the YLS decreased strongly between week 25 and week 29, and this decrease was later observed after week 30 for the number of functional leaves at harvest (NLH) (figure 2). In two other situations, we decided to use a mixture of a DMI with a SBI class II, as the SED did not decrease significantly after previous fungicide applications (applications 5 and 8).
During our experiment, poor deleafing practices and poor crop management resulting in a low foliar emission rate (mean 0.85 leaf over 10 days' duration) were performed by the grower. As a consequence, the YLS and NLH remained in a low position since the leaf emission rate did not compensate for disease development, and the inoculum was persistent in necrotic stages. In spite of this, the conservation of 


\section{Guillermet et al.}

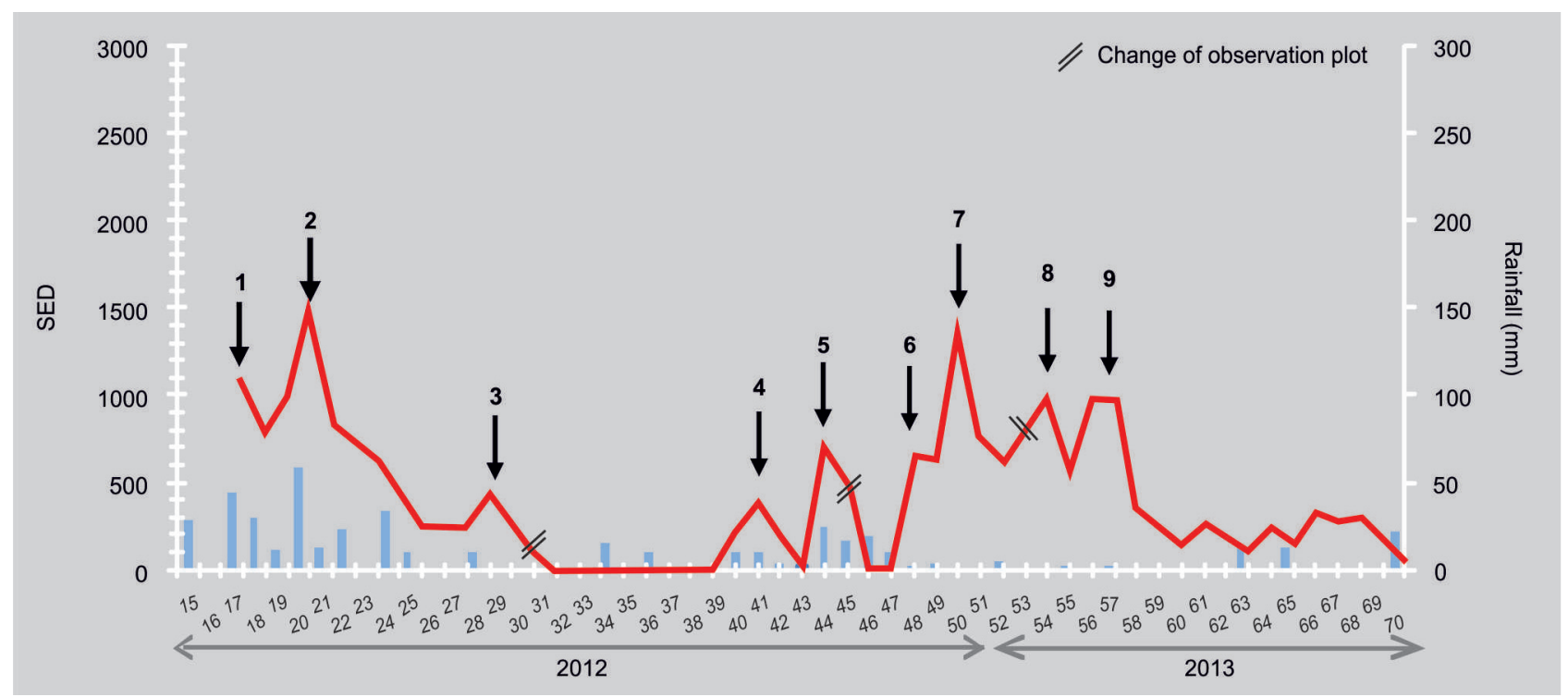

\section{Figure 4.}

Weekly variations of the Stage of Evolution of the Disease (SED) in Palo Amarillo (Dominican Republic).



Figure 5.

Weekly variations of the Youngest Leaf Bearing Streaks (YLSt), Youngest Leaf Spotted (YLS) and Number of Leaves at Harvest (NLH), in Palo Amarillo (Dominican Republic). exported fruit was not affected during the experiment.

\subsubsection{In Palo Amarillo}

Over one year, nine applications were carried out (figures 4, 5, table VII). Delays between the decision and application were reduced to (1 to 3 ) days, thanks to improvements in farmer involvement, product supply and agreement with the spraying company. Fungicide mixtures were carried out in tanks equipped with a rotor, allowing optimum mixing. All of the nine applications were undertaken in good climatic conditions, and the quality of the coverage 


\begin{tabular}{|c|c|c|c|c|c|}
\hline $\begin{array}{l}\text { Number of the } \\
\text { application }\end{array}$ & $\begin{array}{l}\text { Days between decision } \\
\text { and application }\end{array}$ & $\begin{array}{l}\text { Efficiency of the application } \\
\text { (weeks) }\end{array}$ & Product & Active ingredient & Mineral oil \\
\hline 1 & 2 & 3 & Volley $0.5 \mathrm{~L} \cdot \mathrm{ha}^{-1}$ & Fenpropimorph & Spraytex ${ }^{1}$ \\
\hline 2 & 3 & 8 & $\begin{array}{l}\text { Volley } 0.5 \mathrm{~L} \cdot \mathrm{ha}^{-1}+ \\
\text { Opal } 1 \mathrm{~L} \cdot \mathrm{ha}^{-1}\end{array}$ & $\begin{array}{l}\text { Fenpropimorph + } \\
\text { epoxiconazole }\end{array}$ & Banole $^{1}$ \\
\hline 3 & 2 & 12 & Volley $0.5 \mathrm{~L} \cdot \mathrm{ha}^{-1}$ & Fenpropimorph & Banole $^{1}$ \\
\hline 4 & 1 & 3 & Siganex $0.5 \mathrm{~L} \cdot \mathrm{ha}^{-1}$ & Pyrimethanil & Banole \\
\hline 5 & 2 & 4 & Cumora $0.3 \mathrm{~L} \cdot \mathrm{ha}^{-1}$ & Boscalid & Banole $^{2}$ \\
\hline 6 & 2 & 2 & $\begin{array}{l}\text { Volley } 0.5 \mathrm{~L} \cdot \mathrm{ha}^{-1}+ \\
\text { Opal } 1 \mathrm{~L} \cdot \mathrm{ha}^{-1}\end{array}$ & $\begin{array}{l}\text { Fenpropimorph }+ \\
\text { epoxiconazole }\end{array}$ & Banole $^{1}$ \\
\hline 7 & 2 & 4 & Impulse $0.3 \mathrm{~L} \cdot \mathrm{ha}^{-1}$ & Spiroxamine & Banole $^{1}$ \\
\hline 8 & 2 & 3 & Volley $0.5 \mathrm{~L} \cdot \mathrm{ha}^{-1}$ & Fenpropimorph & Banole $^{1}$ \\
\hline 9 & 1 & $>13$ & Reflect $0.6 \mathrm{~L} \cdot \mathrm{ha}^{-1}$ & Isopyrazam & Banole $^{1}$ \\
\hline
\end{tabular}

proved to be good at field level. As a consequence, fungicide applications generally allowed good disease control, as shown by disease-free periods of up to 8 weeks with the SED values equal to zero, or long periods of up to 12 weeks where fungicide applications were not necessary. Here again, the use of a mixture of a DMI with a SBI class II allowed good control (treatment 2), but not in all circumstances (treatment 6). It is also noteworthy that, in dry conditions, the use of a SBI class II or pyrimidins could allow good disease control (treatments 3 and 4). SDHi proved to be effective in BLSD control, particularly in treatment 9 with Reflect, whose formulation is more miscible in oil than Cumora (treatment 5). Lastly, adequate field management allowed a good leaf emission rate (mean 1.1 to 1.3 leaf over 10 days' duration) and generally YLS and NLH evolution did not show a failure in disease control (figure 5).

\subsubsection{In Guayacanes}

Over 12 months, six applications were carried out (figures 6, 7, table VIII). As in Palo Amarillo, applications were carried out within optimal time scales (2 to 3 days), with good mixing and climatic conditions. As a consequence, it allowed good to excellent control, with up to 8 weeks with SED values equal to 0 and long periods up to 19 weeks where fungicide applications were not necessary. As in Palo Amarillo the use of a mixture of a DMI with a SBI class II allowed good disease control in some instances (treatment 5) but not in others (treatment 1). The use of SDHi proved to be effective (treatment 3), as well as the use of a SBI class II in dry conditions (treatments 2 and 6). Good field management allowed a good leaf emission rate (mean 1.1 leaf over 10 days' duration), and YLSt and YLS evolution showed overall good disease control (figure 7).

\subsection{Fungicide resistance analysis after the field experiment}

Fungicide resistance was re-evaluated at the end of the experiment carried out in Esperanza. No changes were observed for QoI and antimitotics. For azoxystrobine ( $t a-$ ble III), sensibility was almost unchanged, and resistant strains were still observed even if no QoI fungicides were used over the last year. Finally, sensibility to benzimidazoles proved to be still very good, even after the two applications carried out (tables $I V$, VI). However, the susceptibility to DMI 


\section{Guillermet et al.}

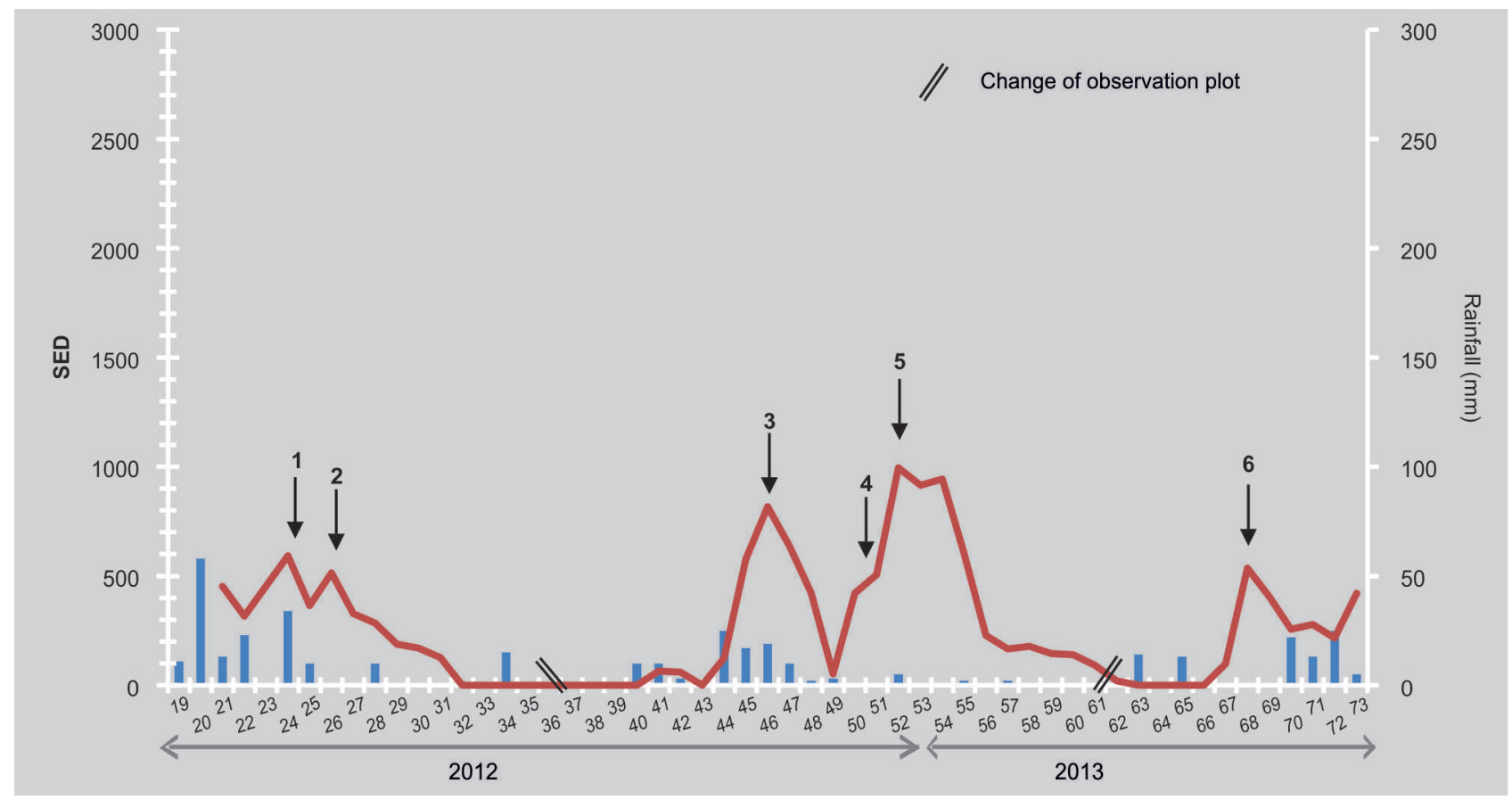

Figure 6.

Weekly variations of the Stage of Evolution of the Disease (SED) in Guayacanes

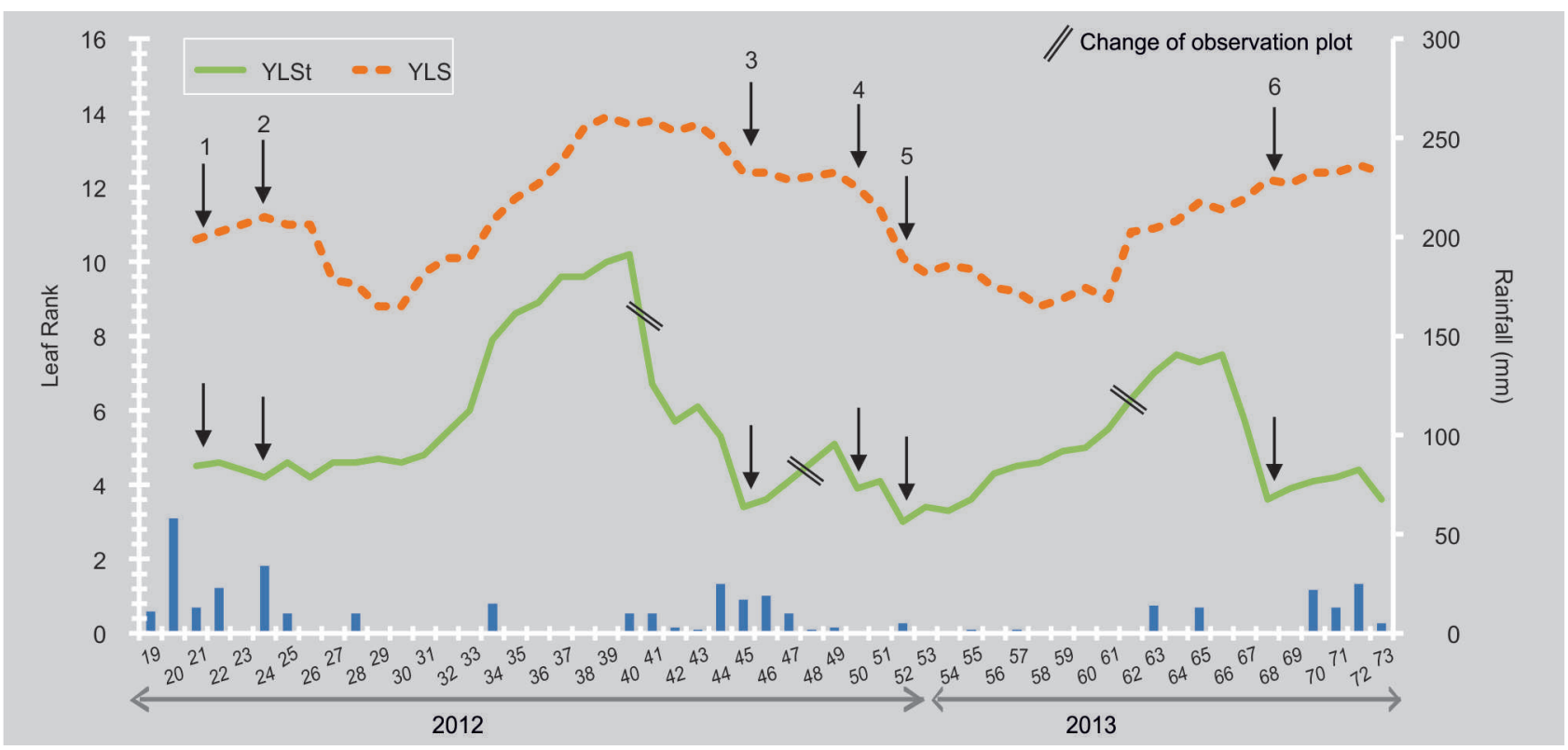

Figure 7.

Weekly variations of the Youngest Leaf Bearing Streaks (YLSt) and Youngest Leaf Spotted (YLS) in Guayacanes (Dominican Republic). fungicides, especially to propiconazole, decreased as a consequence of three applications that were carried out during the experiment with DMI mixed with a SBI class II (tables II, VI). This decrease can be illustrated by the very low average value of the $\%$ of growth inhibition $(\mathrm{GI}=7 \%)$ and by the significant proportion of strains that were slightly inhibited (100\% of strains had a GI < 50\%). 


\begin{tabular}{|c|c|c|c|c|c|}
\hline $\begin{array}{l}\text { Number } \\
\text { of the application }\end{array}$ & $\begin{array}{l}\text { Days between decision } \\
\text { and application }\end{array}$ & $\begin{array}{l}\text { Efficiency of the application } \\
\text { (weeks) }\end{array}$ & Product & Active ingredient & Mineral Oil \\
\hline 1 & 3 & 3 & $\begin{array}{l}\text { Volley } 0.5 \mathrm{~L} \cdot \mathrm{ha}^{-1}+ \\
\text { Opal } 1 \mathrm{~L} \cdot \mathrm{ha}^{-1}\end{array}$ & $\begin{array}{l}\text { Fenpropimorph }+ \\
\text { epoxiconazole }\end{array}$ & Banole $^{1}$ \\
\hline 2 & 2 & 19 & Volley $0.5 \mathrm{~L} \cdot \mathrm{ha}^{-1}$ & Fenpropimorph & Banole $^{1}$ \\
\hline 3 & 2 & 5 & Cumora $0.3 \mathrm{~L} \cdot \mathrm{ha}^{-1}$ & Boscalid & Banole $^{2}$ \\
\hline 4 & 2 & 1 & Impulse $0.3 \mathrm{~L} \cdot \mathrm{ha}^{-1}$ & Spiroxamine & Banole $^{1}$ \\
\hline 5 & 2 & 16 & $\begin{array}{l}\text { Volley } 0.5 \mathrm{~L} \cdot \mathrm{ha}^{-1}+ \\
\text { Sico } 0.4 \mathrm{~L} \cdot \mathrm{ha}^{-1}\end{array}$ & $\begin{array}{l}\text { Fenpropimorph + } \\
\text { difénoconazole }\end{array}$ & Banole $^{1}$ \\
\hline 6 & 2 & $>6$ & Volley $0.5 \mathrm{~L} \cdot \mathrm{ha}^{-1}$ & Fenpropimorph & Banole $^{1}$ \\
\hline
\end{tabular}

\section{Discussion and perspectives}

Our study carried out in three very different sets of conditions at the farm level allows demonstrating that it is possible to adapt the forecasting method to control Black Leaf Streak Disease (BLSD) in the specific conditions of the Dominican Republic: climatic conditions adverse for disease development but strong limitations in the use of some systemic fungicides. Moreover, our study allowed us to highlight critical points to be considered before the implementation of this strategy on a larger scale.

\subsection{A significant reduction in the number of fungicide applications}

The forecasting strategy allowed a significant reduction in the number of fungicide applications in all situations: six applications per year were carried out in Guayacanes, eight in Esperanza and nine in Palo Amarillo. In comparison, in the meantime, most farms located in these areas applied systematic application programs [12] with cycles every (2 to 4) weeks (13 to 26 applications per year). Moreover, our results confirm that the dry season conditions, unfavorable to disease development, provide very favorable conditions for the forecasting strategy. Indeed, disease monitoring showed that it was useless to carry out a new fungicide application for periods as long as 12 weeks in Palo Amarillo, and 19 weeks in Guayacanes.

\subsection{Factors limiting the success of the forecasting strategy}

To evaluate and compare the efficiency of the strategy over the different locations, we calculated an indicator of the efficiency of the chemical control (ECC): $\mathrm{ECC}=($ SEDy $) \times$ $\mathrm{Ny}$, where SEDy is the average of the weekly values of the SED over one year in a location and $\mathrm{Ny}$ is the number of fungicide treatments applied in one year in this same location [3]. The lower the ECC, the more efficient the chemical control strategy, as it means that a good control of BLSD was achieved (low average value of the SED), with a low number of fungicide treatments.

These calculations show that the best efficiency of the forecasting strategy was achieved in Guayacanes, with an ECC lower than 2000, and the worst in Esperanza (table IX).

\subsubsection{Influence of farm environment}

Since the Guayacanes and Palo Amarillo experiments were performed over the same climatic period, these situations might be 


\section{Guillermet et al.}

\begin{tabular}{|c|c|c|c|}
\hline Experiment & $\begin{array}{l}\text { Mean SED } \\
\text { over } 1 \text { year }\end{array}$ & $\begin{array}{c}\text { Number of applications } \\
\text { over } 1 \text { year }\end{array}$ & ECC \\
\hline Esperanza & 767 & 9.2 (8 applications over 45 weeks) & 7087 \\
\hline Palo Amarillo & 410 & 9 & 3692 \\
\hline Guayacanes & 266 & 6 & 1598 \\
\hline
\end{tabular}

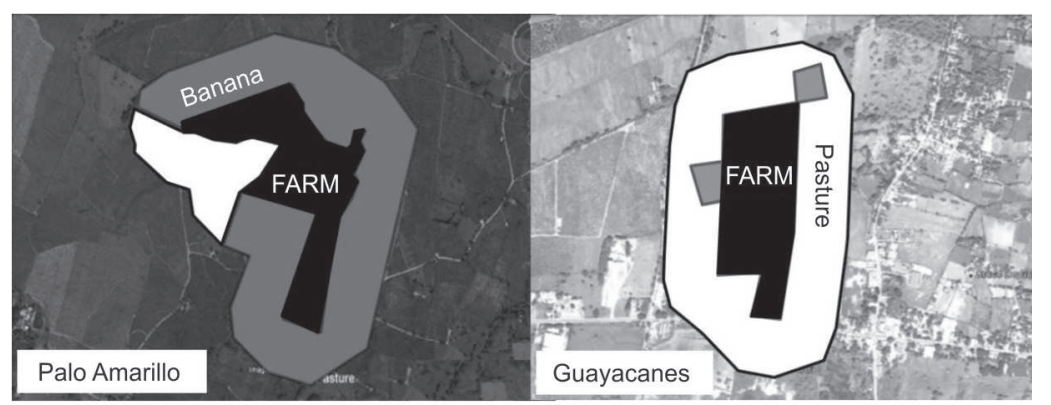

Figure 8.

Environment of the commercial farms where a forecasting strategy was tested in 2012. Palo Amarillo (left) and Guayacanes (right). Various geographical features situated in a $200-\mathrm{m}$ border are indicated: [gray: banana or plantain; white: pasture or other crop (except banana); black: experimental farm]. compared and the better performance of the strategy in Guayacanes (table $I X$ ) might be explained by geographical features. Since ascospores of $M$. fijiensis disperse at long distances [27], and on average at $200 \mathrm{~m}$, we considered the geographical features within a border of $200 \mathrm{~m}$ around each banana plot. This analysis showed that Guayacanes farm is quite isolated: $82 \%$ of this border is grown with bananas in Palo Amarillo, versus only $5 \%$ in Guayacanes (figure 8). Furthermore, many of the bananas grown in the border of the Palo Amarillo farm suffer from bad phytosanitary control, making them many potential inoculum sources of ascospores.

\subsubsection{Influence of agronomic practices}

The worse efficiency of the strategy in the Esperanza farm (table IX) confirms that better plant growth management, with adequate fertilization and irrigation, is essential to optimize the efficiency of the chemical strategy. Indeed, the agronomic management was very poor in the Esperanza farm as compared with the two other farms. Particularly, good agronomic practices are essential to optimize the leaf emission rate (LER), and compensate for disease reduction of the leaf area. It is stated that a minimum LER of one leaf a week should be targeted. Overall, better management of the field inoculum needs to be achieved, in order to limit new contamination inside the same farm, and between close farms, as their influence proved to be significant in the Palo Amarillo experiment.

\subsubsection{Influence of timing in decisions and carrying out the applications}

Significant delays in applications (over $48 \mathrm{~h}$ ) proved to impact the efficiency of the applications in the Esperanza farm significantly, especially at the beginning of the experiment. Shortening delays in the decision and undertaking of fungicide applications is a key component to the success of the forecasting strategy [19, 20]. Thus, as expected in the Palo Amarillo and Guayacanes farms, a better efficiency of the strategy was achieved thanks to specific agreements with the spraying company that allowed a faster carrying out of fungicide applications, within $48 \mathrm{~h}$, and in the best meteorological conditions (early in the morning when the temperature does not exceed $27^{\circ} \mathrm{C}$ ).

\subsubsection{Influence of fungicide resistance}

Considering the dry climatic conditions in the Dominican Republic, good control of BLSD with a lower number of fungicide applications should be expected, since, in similar climatic conditions in Ghana, only 56 applications per year are necessary for very good BLSD control (Compagnie Fruitière, pers. commun.). One of the objectives of our study was to evaluate whether the forecasting strategy could still be efficient in a context where the use of some systemic 
fungicides is limited by fungicide resistance. Our results showed that, in spite of a greater number of fungicide applications than expected, the forecasting strategy was still efficient in the conditions of the Dominican Republic. Particularly, we showed that the use of DMI fungicides mixed with a SBI class II allowed efficient control of the disease in farms where sensitivity to this group of fungicides was significantly reduced. This alternative was necessary because other fungicides with a strong curative effect (antimitotics, QoI, SDH inhibitors) were not available or could not be used. Indeed, the curative effect of the SBI class II and pyrimidines is too low to allow good disease control in high outbreak situations. Nevertheless, we also showed that this use of DMI fungicides, even if limited, could worsen the level of fungicide resistance to these fungicides. The use of DMI fungicides must therefore be very limited. The registration of a new group of fungicides, the $\mathrm{SDH}$ inhibitors, in Dominican Republic (isopyrazam, fluopyram, boscalid) provide a new alternative as high curative effect fungicides as they do not have cross-resistance with other groups. This was confirmed by the applications carried out in Palo Amarillo and Guayacanes, especially using Reflect. Furthermore, availability of antimitotic products usable in oil should also be investigated in Dominican Republic, since fungal populations of this country remain susceptible to this group of fungicides, which is known as an efficient tool for BLSD control [21].

\subsection{Considerations for a future extension of this strategy to banana farms of Dominican Republic}

While the forecasting method proved to be efficient in controlling disease on a single farm scale, consequent organizational issues need to be arranged within the different producers' associations before further implementation on a larger scale:

1) Banana farms should be sectored into functional spraying areas (100-200 ha) where disease development is homogeneous. These areas would include various farmers that would follow the same disease control strategy. To determine these areas, it will be essential to take into account the particularity of this country where organic and conventional farms are closely located in the same vicinity.

2) Decisions must be centralized within a technical team, responsible for decisions of fungicide applications and for the selection of the most adequate products, based on technical criteria, instead of the current individual decisions.

3) The logistics of aerial applications must be reorganized to avoid long delays in their undertaking, and to ensure that applications are undertaken in optimal climatic conditions for all farmers located within the same spraying area.

4) High curative effect fungicides must be selected. These products must be compatible for a mix in pure mineral oil, as its use will reinforce the curative effect of the treatment.

5) The different products must be used rationally in order to manage fungicide resistance. The general guideline is to alternate fungicides with different mode of actions, and the strategy must be driven by regular fungicide resistance monitoring.

6) The strong heterogeneity in the implementation of agronomic practices to eliminate inoculum sources and to optimize the leaf emission rate must be considered to evaluate the efficiency of the chemical strategy.

Therefore, significant changes in the organization of the Dominican banana sector are required before further large-scale implementation of this strategy in this country. Nevertheless, without this reorganization, BLSD will keep challenging the evolution of the banana industry, as its control will be more and more difficult and expensive, potentially compromising its sustainability.

\section{Acknowledgments}

We acknowledge the association of Dominican banana farmers, Adobanano, and UGPBAN for organizational support; and the 
farmers from Coopabando (Adolfo Madera and Guarionex Garcia) who agreed to implement these experiments on their farms. The authors also acknowledge L. Deana for technical assistance, and J. Carlier and M.F. Zapater, UMR BGPI, for laboratory facilities during fungicide resistance analysis in Montpellier (France). This research was supported by European funding from the program Interreg IV Caraibes, through the project 'Sustainable banana in the Caribbean'.

\section{References}

[1] Lescot T., La banane en chiffres : le fruit préféré de la planète, FruiTrop 140 (2006) 5.

[2] Loeillet D., Le commerce international de la banane : entre évolution et révolution, FruiTrop 129 (2005) 2-19.

[3] de Lapeyre de Bellaire L., FouréE., Abadie C., Carlier J., Black Leaf Streak Disease is challenging the banana industry, Fruits 65 (2010) 327-342.

[4] Ramsey M.D., Daniells J.W., Anderson D.J., Effects of Sigatoka leaf spot (Mycosphaerella musicola Leach) on fruit yields, field ripening and greenlife of bananas in North Queensland, Sci. Hortic. 41 (1990) 305-313.

[5] Stover R.H., Effet du cercospora noir sur les plantains en Amérique centrale, Fruits 38 (1983) 326-329.

[6] Maciel Cordeiro Z.J., Pires de Matos A., Impact of Mycosphaerella spp. in Brazil, in: Mycosphaerella leaf spot disease of banana: present status and outlook, Jacome L., Lepoivre P., Marin D., Ortiz R., Romero R. Escalant J.V., Proc. Workshop on Mycosphaerella Leaf Spot Diseases, San José, Costa Rica, 20-23 May 2002, 317 p., INIBAP, Montpellier, France, 2003, pp. 91-97.

[7] Stover R.H., Banana, plantain and abaca diseases, Commonw. Mycol. Inst., Kew, Surrey, U.K., 1972.

[8] Jullien A., Croissance, développement et qualité des fruits du bananier (Musa spp. groupe AAA cv. 'Grande Naine'). Modélisation de la répartition des assimilats entre les fruits du régime, Inst. Ntl. Agron. ParisGrignon, Thèse, Paris, France, 2000, 92 p.

[9] Abadie C., Hubert O., Ngando Essoh J., Ngoh G., Mbéguié-A-Mbéguié $D$., de Lapeyre de Bellaire L., Chillet M., Evidence of the effects of Mycosphaerella leaf spot diseases on fruit quality, in: Borja J.S., Nogales C., Orrantia C., Paladines R., Quimí V., Tazán L. (Eds.), Mem. XVIIIth ACORBAT meeting, Guayaquil, Ecuador, 10-14 Nov. 2008.

[10] Chillet M., Abadie C., Hubert O., ChilinCharles Y., de Lapeyre de Bellaire L., Sigatoka disease reduces the greenlife of bananas, Crop Prot. 28 (2009) 41-45.

[11] Polegato Castelan F., Amorim Saraiva L., Lange F., de Lapeyre de Bellaire L., Cordenunsi B., Chillet M., Effects of Black Leaf Streak Disease and Sigatoka Disease on the green life of bananas produced in the subtropical conditions of Southern Brazil, Crop Prot. 35 (2011) 127-131.

[12] Anon., Situación actual de la Sigatoka negra en la República Dominicana, Reunión interinstitucional sobre manejo de la Sigatoka negra, Adobanano (Asociación Dominicana de Productores de Banano), Mao, Valverde, Dominican Republic, 23 Nov. 2011.

[13] Anon., Proyecto de diversificación económica rural, iniciativas de fortalecimiento a los clusters del sector agropecuario dominicano, desarrollo e implementación de un plan de marketing para el mercado dominicano en el cluster de banano, USAID-RED, Santo Domingo, Dominican Republic, 2009, $46 \mathrm{p}$.

[14] Céspedes C., Distribución, epidemiología y manejo de la Sigatoka Negra en la República Dominicana, Inst. Domin. Invest. Agropecu. For. (IDIAF), Santo Domingo, Dominican Republic, 2008.

[15] Fouré E., La maladie des raies noires des bananiers et plantains en République dominicaine. Distribution, incidence et méthodes de contrôle, Rapport de mission en République dominicaine du 28 août au 5 septembre 1997, CIRAD-FHLOR, Montpellier, France, 1997.

[16] Jorge P.E., Polanco T., Spread and management of black leaf streak disease in the Dominican Republic, in: Mycosphaerella leaf spot disease of banana: present status and outlook, Jacome L., Lepoivre P., Marin D., Ortiz R., Romero R., Escalant J.V., Proc. Workshop on Mycosphaerella Leaf Spot Diseases, San José, Costa Rica, 20-23 May 2002, 317 p.

[17] Fouré E., Stratégies de lutte contre la cercosporiose noire des bananiers et plantains provoquée par Mycosphaerella fijiensis Morelet. L'avertissement biologique au 
Cameroun. Evaluation des possibilités d'amélioration, Fruits 43 (1988) 269-274.

[18] Fouré E., Ganry J., A biological forecasting system to control Black Leaf Streak disease of bananas and plantains, Fruits 63 (2008) 311-317.

[19] Ganry J., de Lapeyre de Bellaire L., Mourichon X., A forecasting system to control Sigatoka disease, Fruits 63 (2008) 381-387.

[20] Ganry J., Fouré E., de Lapeyre de Bellaire L., Lescot T., An integrated approach to control the Black Leaf Streak Disease (BLSD) of bananas, while reducing fungicide use and environmental impact, in: Dhanasekaran D., Thajuddin N., Panneerselvam A. (Eds.), Fungicides for plant and animal diseases, InTech (2012) 193-226.

[21] de Lapeyre de Bellaire L., Essoh Ngando J., Abadie C., Chabrier C., Blanco R., Lescot T., Carlier J., Côte F., Is chemical control of Mycosphaerella foliar diseases of bananas sustainable? Acta Hortic. (ISHS) 828 (2009) 161-170.

[22] de Lapeyre de Bellaire, L., Rapport de mission en République dominicaine du 7 au
14 février 2011, CIRAD, Montpellier, France, 2011.

[23] Fouré E., La maladie des raies noires des bananiers et plantains M. fijiensis (Morelet), Étude comparée des différents symptômes et stades de la maladie au Gabon, IRFACIRAD (France), SONADECI (Gabon), 1982.

[24] de Lapeyre de Bellaire L., Risede, J.M., A laboratory method to evaluate Pseudocercospora musae's (Teleomorph: Mycosphaerella musicola) sensitivity to fungicides, Fruits 63 (2008) 53-56.

[25] Brun J., Étude sur l'action des fongicides huileux dans la lutte contre la cercosporiose, Fruits 13 (1958) 3-14.

[26] Cuillé J., Blanchet B., Les huiles de traitements, leur phytotoxicité, Fruits 13 (1958) 53-65.

[27] RieuxA., Soubeyrand S., BonnotF., Carlier J., Ravigne V., Klein E.K., Ngando J. E., Melh A., de Lapeyre de Bellaire L., Blowin' in the wind: direct estimation of long-distance anisotropic dispersal kernels in an airborne fungal plant pathogen, Plos Pathogens, Submitted (2013). 


\section{Adaptación del sistema de aviso biológico de la enfermedad de las rayas negras en las condiciones específicas de la República Dominicana.}

Resumen - Introducción. La enfermedad de las rayas negras (ERN) es la enfermedad foliar que afecta a la producción bananera más importante en el mundo. Se desarrolló un sistema de aviso biológico y se puso en marcha en varios países con el objetivo de controlar de forma óptima la ERN con un número mínimo de aplicación de fungicidas. En la República Dominicana, las condiciones climáticas secas son favorables para controlar la enfermedad, pero contrastan con los importantes vacíos organizacionales. Nuestro objetivo pretendió evaluar la adaptación de la estrategia de aviso en estas condiciones específicas. Material y métodos. Se realizaron análisis de resistencia a los fungicidas en la región del noroeste del país con el fin de determinar la gama de fungicidas apropiada para el aviso. Se ejecutaron tres experimentos en plantaciones comerciales con un seguimiento semanal de la evolución de la enfermedad, en puestos de referencia, para decidir la pertinencia de la realización de un tratamiento. Resultados. Se detectaron una resistencia a los fungicidas de tipo QoI y una fuerte reducción de la sensibilidad a los DMI (Demethylation Inbibitors) en todas las plantaciones. A pesar de estas limitaciones en el uso de ciertos grupos de fungicidas, la enfermedad pudo controlarse con un número limitado de tratamientos (6 a 9), frente a 13 a 26 tratamientos efectuados en la mayoría de las plantaciones comerciales del país en el mismo periodo. Discusión. El cálculo de un indicador de eficacia del control químico confirmó el interés de la estrategia de aviso, subrayando la influencia de las prácticas culturales, así como la del entorno vecino a la plantación en su eficacia. Se discuten las disposiciones necesarias para la generalización de este sistema en las plantaciones comerciales del país.

República Dominicana / Musa / control de enfermedades de plantas / Mycosphaerella fijiensis / técnicas de predicción 